Jurnal Kesehatan Masyarakat

\title{
CHARACTERISTICS OF SCAVENGERS WITH SKIN DISEASES IN WUKIRSARI LANDFILL, GUNUNG KIDUL, YOGYAKARTA
}

\author{
Novianingrum, Surahma Asti Mulasari ${ }^{\bowtie}$ \\ Departement of Public Health Science, Universitas Ahmad Dahlan, Yogyakarta
}

\begin{tabular}{l} 
Article Info \\
\hline Article History: \\
Submitted Januari 2016 \\
Accepted November 2017 \\
Published November 2017 \\
\hline Keywords: \\
skin diseases; character- \\
istics scavengers; landfill \\
\hline DOI \\
http://dx.doi.org/10.15294/ \\
kemas.v13i2.4729 \\
\hline
\end{tabular}

\section{Introduction}

Population growth, economic growth, rapid urbanization, and increased standard of living has accelerated garbage accumulation (Guerrero, 2013). Garbage is a problem that society had to face because garbage is the result of human activity. Each year garbage continue to accumulate as population grows, standard of living increases and technology advances, resulting in a shift to a more consumptive community (Yansen, 2012).

Garbage are useless waste products produced by houses or company/industry. When managed properly garbage is not harmful, but if managed poorly it could be harmful and cause illness because garbage can become a breeding site of disease vectors. As a profession with high contact to garbage, scavengers have a greater risk of being exposed to pathogens in garbage that can affect their health (Mayuni, 2012). From Indonesia health profile in 2010, the number of skin disease cases in Indonesia was 122,076 cases. From RISKESDAS (2007), the prevalence of dermatitis in Indonesia was 6.78\% (Aisyah, 2012).

Rapid city development, difficulty to find employment, and other unresolved problems related to labor in a country encourage urbanization because rural population hope to find employment in the city. However, some of the migrants had to survive by being scavengers due to increase in population, unemployment, and their relatively low human resource quality (Fadillah, 2010).

Scavengers are people whose job is collecting materials or goods that was disposed 
as garbage, then selecting, cleaning, and transforming the garbage's appearance to sell for money. Health risk related to garbage collection is something to pay attention to (Thirarattanasunthon, 2012).

Landfills are places that could affect the health of scavengers because in landfills there are piles of garbage where all kinds of bacteria and virus gather and multiply. Poor garbage management could negatively impact health, one of them is skin diseases (Mustikawati, 2013).

When working, scavenger should wear complete Personal Protection Equipment (PPE) to protect himself from garbage or sharp materials in landfills. One of the most frequent disease is skin diseases. From 20 scavengers observed, 10 scavengers did not use mask, 6 scavengers did not wear head cover and shoes, 2 scavengers did not wear shirt and only 2 wore gloves, head covers, mask, and shoes. Head covers and boots worn by scavengers are dirty and shabby. There was a scavenger who wore shoes but used plastic bags out of the garbage as his socks. The scavengers wore layered shirts to avoid direct contact with garbage, but the outermost layer was not washed before reuse unless it is very dirty. This shows lack of hygiene and PPE usage among scavengers. All of the scavengers observed had history of skin diseases such as itches and red skin.

Method

This study is cross-sectional study. The population in this study were all 32 scavengers who worked in Wukirsari Landfill Gunungkidul Yogyakarta. Samples were collected using totality sampling, which include all population as sample in this study. This study used instruments as questionnaire, checklist, and medical doctor diagnosis as primary data, and data from UPT Wukirsari Landfill Gunungkidul Yogyakarta for secondary data. Observation and measurement results was analyzed using univariate and bivariate analysis. Univariate analysis was used to describe scavengers characteristic, whereas bivariate analysis using Chi-Square test was used to find the relationship between scavenger characteristic and incidence of skin diseases. $\mathrm{P}$ value $<$ alpha $(<0.05)$ shows statistically significant relationship, while $\mathrm{P}$ value $>0.05$ shows otherwise.

\section{Result and Discussion}

The result of this study is data about the characteristics of scavengers in Wukirsari landfill, Gunung Kidul district such as age of respondent, sex, education level, personal hygiene, duration of work, PPD usage and incidence of skin disease. The data is shown in the following table:

Table 1 shows that most respondents were aged more than 35 years $(68.8 \%)$, while the rest were $20-35$ years old (31.2\%). The distribution of sex was more male than female; $18(56.2 \%)$ vs $14(43.8 \%)$ people. $46.9 \%$ (15 persons) respondents in this study were primary school graduate, then the second highest did not attend school $21.9 \%$ (7 persons), the third were junior high school graduate $18.8 \%$ (6 persons), and the least were high school graduate $12.5 \%$ (4 people). For personal hygiene of respondents in this study, $59.4 \%$ respondents (19 people) did not have good personal hygiene while 40.6\% (13 people) had good personal hygiene. For the respondent's duration of work 18 people $(56.2 \%)$ had long working period, while the new scavenger were14 people (43.8\%). The scavengers who wore complete Personal Protective Equipment (PPE) while working were 18 people $(56.2 \%)$ while 14 people $(43.8 \%)$ did not use complete PPE while working. Respondents with history of skin disease were 17 people (53.1\%) while 15 people (46.9\%) did not have history of skin diseases.

The relationship between hygiene personal with the incidence of skin diseases could be seen in table 2 , which shows that among 19 scavengers with poor personal hygiene, 14 had history of skin diseases, while from 13 scavengers with good personal hygiene, only 3 had history of skin diseases. Using chi-square test, we obtained $p$ value $=0.005$ with $\alpha=0.05$, showing that there is a statistically significant relationship between personal hygiene and history of skin disease among scavengers. The magnitude of risk can be seen from RP value $=3.193$ (95\% CI:1.142-8.928) which means that scavengers with poor hygiene has 3.193 times higher risk to suffer from skin disease.

From the results of the research, it can be concluded that scavengers with poor personal hygiene would be more vulnerable to various diseases such as skin disease. 
Tabel 1. Characteristic Distribution among Scavengers in Wukirsari Landfill Gunung Kidul in 2014.

\begin{tabular}{|c|c|c|}
\hline Characteristics & Frequency & Percentage \\
\hline \multicolumn{3}{|l|}{ Age of respondents } \\
\hline 20 to 35 years old & 10 & 31.2 \\
\hline More than 35 years old & 22 & 68.8 \\
\hline \multicolumn{3}{|l|}{ Sex } \\
\hline Male & 18 & 56.2 \\
\hline Female & 14 & 43.8 \\
\hline \multicolumn{3}{|l|}{ Education level } \\
\hline Not educated & 7 & 21.9 \\
\hline Primary school & 15 & 46.9 \\
\hline Junior high school & 6 & 18.8 \\
\hline Senior high school & 4 & 12.5 \\
\hline \multicolumn{3}{|l|}{ Personal Hygiene } \\
\hline Tidak baik & 19 & 59.4 \\
\hline Baik & 13 & 40.6 \\
\hline \multicolumn{3}{|l|}{ Duration of work } \\
\hline Long & 18 & 56.2 \\
\hline New & 14 & 43.8 \\
\hline \multicolumn{3}{|l|}{ PPD usage } \\
\hline Incomplete & 14 & 43.8 \\
\hline Complete & 18 & 56.2 \\
\hline \multicolumn{3}{|l|}{ History of skin disease } \\
\hline Positive & 17 & 53.1 \\
\hline Negative & 15 & 46.9 \\
\hline \multicolumn{3}{|l|}{ Age of respondents } \\
\hline 20 to 35 years old & 10 & 31.2 \\
\hline More than 35 years old & 22 & 68.8 \\
\hline \multicolumn{3}{|l|}{ Sex } \\
\hline Male & 18 & 56.2 \\
\hline Female & 14 & 43.8 \\
\hline \multicolumn{3}{|l|}{ Education level } \\
\hline Not educated & 7 & 21.9 \\
\hline Primary school & 15 & 46.9 \\
\hline Junior high school & 6 & 18.8 \\
\hline Senior high school & 4 & 12.5 \\
\hline
\end{tabular}

Source : Primary Data

This study is not in line with other studies with the title of "Hubungan Hygiene Perorangan dan Pemakaian Alat Pelindung Diri Dengan Keluhan Gangguan Kulit Pada Pekerja Pengupas Udang Di Kelurahan Pekan Labuhan Kecamatan Medan Labuhan tahun 2012", which stated that there is no relationship between personal hygiene with skin disorder (Aisyah, 2012).
Personal hygiene is one of the basic human capabilities to fulfill their needs and maintain their health, life, and well-being. A person is said to have poor personal hygiene when unable to self-care (Aisyah, 2012). Individual hygiene behavior is health activities and actions aimed to maintain good health, and prevent the occurrence of disease (Wirawan, 2011). Personal hygiene is a daily activity but 
Table 2. The Relationship between Characteristic Data and Skin Disease among Scavengers in Wukirsari Landfill Gunungkidul Yogyakarta in 2014.

\begin{tabular}{|c|c|c|c|c|c|c|}
\hline & \multicolumn{3}{|c|}{ Kejadian Penyakit Kulit } & \multirow[t]{2}{*}{ p-value } & \multirow[t]{2}{*}{$\mathrm{RP}$} & \multirow[t]{2}{*}{ CI (95\%) } \\
\hline & Sakit (\%) & $\begin{array}{l}\text { Tidak sakit } \\
(\%)\end{array}$ & $\mathrm{N}(\%)$ & & & \\
\hline $\begin{array}{l}\text { Personal Hygiene } \\
\text { Tidak baik } \\
\text { Baik }\end{array}$ & $\begin{array}{l}14 \\
3\end{array}$ & $\begin{array}{l}5 \\
10\end{array}$ & $\begin{array}{l}19 \\
13\end{array}$ & 0.005 & 3.193 & $1.142-8.928$ \\
\hline $\begin{array}{l}\text { Masa Kerja } \\
\text { Lama } \\
\text { Baru }\end{array}$ & $\begin{array}{l}10 \\
7\end{array}$ & $\begin{array}{l}8 \\
7\end{array}$ & $\begin{array}{l}18 \\
14\end{array}$ & 0.755 & 1.111 & $0.570-2.165$ \\
\hline $\begin{array}{l}\text { Penggunaan APD } \\
\text { Tidak lengkap } \\
\text { Lengkap }\end{array}$ & $\begin{array}{l}12 \\
5\end{array}$ & $\begin{array}{l}2 \\
13\end{array}$ & $\begin{array}{l}14 \\
18\end{array}$ & 0.001 & 3.086 & $1.422-6.698$ \\
\hline
\end{tabular}

Source : Primary Data

sometimes it is still considered less important. This problem is caused by lack of socialization and general knowledge about the importance of personal hygiene, hence it is difficult to implement clean and healthy behavior in the community, especially among people who work with garbage (Azizah, 2011).

Personal hygiene can be seen from the cleanliness of hands, feet, skin, nail, clothing and living place. All body parts should always be clean, for example by bathing, brushing teeth, washing clothes and cleaning houses. Cleanliness is important so that germs cannot cause disease, especially for scavengers. The scavengers have been perceived as dirty and smelly because they are associated with dirty places, therefore it is important for them to pay attention to personal hygiene after working (Sajida, 2012).

For their protective clothing, scavengers assume that by using layers of clothing they will be protected from direct contact with garbage. Clothes are used for days without being washed, only air dried, unless the clothes look dirty. The next day the clothes are reused. However wearing layered clothes, the activity of sweat glands would increase, increasing the moisture which can invite bacteria, fungi, or parasites that can cause skin diseases.

Analysis of the relationship between duration of work and the incidence of skin diseases shows that out of the 18 scavengers who had long working duration of work, 10 scavengers had history of skin diseases, while out of 14 scavengers with new duration of work, 7 had history of skin diseases.

The result of statistical test using chisquare found the value of $p=0.755$ at $\alpha=0.05$. It means that the relationship between the working period and incidence of skin diseases was not statistically significant. The amount of risk could be seen from the value of $\mathrm{RP}=$ 1.111 (95\% CI: 0.570-2.165) which means that scavengers with long duration of work had a risk of skin diseases 1,111 times higher compared to those with new work duration.

The duration of exposure to germs from garbage is still a risk for skin diseases. Scavengers with long duration of work is more likely to be exposed to various diseases from garbage. The longer a person is exposed to the workplace, the greater the risk of affected by diseases from its workplace, one of the disease is skin disorder. This study is not in line with other studies with the title of factors related to the incidence of dermatitis among fishermen; because the value of $p=0.0001$, it means that there is a relationship between duration of work and incidence of dermatitis (Cahyani, 2011).

Worker's health status is influenced by 4 factors: worker's environment, worker's behavior, occupational health service and genetic factors. Worker's environment is the most important factor for scavengers. Working as a scavenger requires one to be exposed directly to garbage and irritant agents in the garbage which will directly damage the outer layer of the skin or reducing the skin's endurance 
(Azhar, 2011).

A person's duration of work can also create health problems, because various diseases could manifest in people with long duration of work. The longer a person works in an environment where there is high-intensity garbage, the more likely he would be exposed to various diseases that come from garbage such as skin diseases (Burhanudin, 2008).

Long duration of work as a scavenger could negatively influence scavengers' health. The longer the duration of work as scavengers, the risk for contracting diseases also increases. The disease can occur due to physical, chemical, or biological factors, directly or indirectly, and would influence scavengers' safety and health.

Skin disorders caused by fungi usually have long incubation period. The longer a person works in an environment where there is high-intensity garbage, the greater the exposure to various diseases related to garbage such as skin diseases. A short working period could also affect health. This can also be influenced by other factors such as duration of exposure to irritants per day. Hence, even when they have not worked for a long time as a scavenger, there is still a risk of contracting skin disease.

Analysis of the relationship between usage of PPE and the incidence of skin diseases showed that out of 14 scavengers who used incomplete PPE, 12 suffered skin diseases, while out of 18 scavengers who used complete PPE, only 5 experienced skin disease.

The result of statistical test using chisquare found the $p$ value $=0.001$ at $\alpha=0.05$, it can be concluded that there is a statistically significant relationship between usage of PPE and the incidence of skin diseases on garbage scavengers. The amount of risk can be seen from the value of $\mathrm{RR}=3.086$ (95\% CI: 1.422-6.698) meaning that scavengers who used incomplete PPE had a risk of skin diseases 3,193 times higher compared to those who used complete PPE.

It can be concluded that PPE usage is very important to protect scavengers from direct contact with garbage. Therefore scavengers should wear complete PPE while working to prevent various diseases, especially skin diseases. From the results of the study, the incidence of skin disease was higher among scavengers in Wukirsari landfill Gunungkidul who wore incomplete PPE compared to those who wore complete PPE.

Personal Protective Equipment (PPE) is a set of tools used by workers to protect themselves from objects or materials that may endanger health or safety during work (Azizah, 2011). PPE is important to be worn when scavengers and garbage collectors work, because when working they would have direct contact the accumulation of various garbage, which is a source for various diseases such as skin diseases. Scavengers who do not wear complete PPE would facilitate the entry of various diseases into the body through the hands, feet, body, and head (Burhanudin, 2008). Improper usage could also make scavengers and garbage collector suffer from skin disorders, such as the usage of gloves and foot holsters that are not appropriate to skin type and environmental type, especially for people who are sensitive to PPE materials who sometimes choose not to wear PPE when in contact with garbage (Ningtyas, 2013).

Complete PPE consists of several components, namely a head protector (hat, headgear) that will protect the head from impact; foot protective equipment such as shoes made of leather, synthetic rubber, or plastic. There are several customized equipments such as anti-slip soles to prevent slipping, metal soles to prevent puncture, sewn or taped shoes to prevent electrical hazards. Hand protection tool such as rubber gloves to protect from sharp objects such as broken glass, needle etc. Hand protection devices are essential for garbage collectors to avoid direct contact between limbs (hands) and garbage (Adnani, 2010).

During garbage collection, there are scavengers who only wore cloth shoes, sometimes even flip-flops, and wore layered clothing. Most scavengers did not wear gloves for comfort reasons although they worked for a long time; some even wore cloth gloves that is already unsuitable because it is already torn, dirty, and full of holes. This condition is obviously insufficient for their occupational safety and health because their hand will contact the garbage directly. This is also true for their feet when they step onto the pile of garbage, causing them to become dirty due 
to direct contact with the pile of garbage. Inadequate personal protective equipment could not protect a worker from work accident or occupational illness.

\section{Conclusion}

Based on this study, we can conclude that there is a relationship between personal hygiene and the incidence of skin diseases among scavengers in TPA Wukirsari Gunungkidul Yogyakarta $(\mathrm{RP}=3.193$; CI 95\% : 1.142-8.928 and $\mathrm{p}$ value $=0.005)$. There is no statistically significant relationship between scavenger's years of service and the incidence of skin diseases among scavengers in TPA Wukirsari Gunungkidul Yogyakarta in 2014 ( $\mathrm{RP}=1.111$; CI 95\%: 0.570 - 2.165; and $p$ value 0.755 ). We also found significant relationship between usage of PPE and the incidence of skin diseases among scavengers in TPA Wukirsari Gunungkidul Yogyakarta in $2014(\mathrm{RP}=3.086$; CI 95\%: 1.422 - 6.698; and $\mathrm{p}$ value 0.001 ). Variables that had a relationship with incidence of skin disease were personal hygiene and usage of PPE. After multivariate analysis, the most influential factor was usage of PPE with $\mathrm{p}=0.022$.

\section{References}

Adnani, H. 2010. Perilaku Petugas Pengumpul Sampah Untuk Melindungi DirinyaDari Penyakit Bawaan Sampah Di Wilayah Patangpuluhan Yogyakarta Tahun 2009" Jurnal Kesehatan Masyarakat, 4 (3) : 144-239.

Aisyah, F. Santi, N.U. Chahaya, I. 2012. Hubungan Hygiene Perorangan DanPemakaian Alat Pelindung Diri Dengan Keluhan Gangguan Kulit Pada Pekerja Pengupas Udang Di Kelurahan Pekan Labuhan Kecamatan Medan Labuhan. Jurnal Lingkungan dan Kesehatan Kerja, 2 (2) : 1-9.

Azhar, K., Hananto, M. 2011. Hubungan Proses Kerja Dengan Kejadian DermatitisKontak Iritan Pada Petani Rumput Laut Dikabupaten Bantaeng Sulawesi Selatan. Jurnal Ekologi Masyarakat, 10 (1) : 1-9

Azizah. Setiyowati. 2011. Hubungan Tingkat Pengetahuan Ibu Tentang PersonalHygiene dengan Kejadian Skabies Pada Balita di Tempat PembuanganAkhir Kota Semarang. Jurnal Dinamika Kebidanan, 1 (1), Januari $2011: 1-9$.

Burhanudin., Budiyono,H., Mulasari,S.A, 2008,
Faktor-Faktor yang Berhubungan dengan Kelainan Kulit Secara Subyektif Petugas Pengangkut Sampah di Kota Yogyakarta", Jurnal Penelitian dan Kajian Ilmiah Kesehatan Masyarakat, 2 (1) : 43-53.

Cahyani. Budiono. 2011. Faktor yang Berhubungan Dengan Kejadian DermatitisPada Nelayan. Jurnal Kesehatan Masyarakat, 6 (2) : 134-141. Fadillah, N dan Dastina, W. 2010. Keluarga Pemulung di Kelurahan Legok, KecamatanTelanaipura kota Jambi. Jurnal Media Akademika, 25 (4) : 311-329.

Guerrero, L.A., Maas, G.,Hogland, W. 2013. Solid Waste Management Challenges For Cities In Developing Countries. Journal Elsevier, 33 : 220-232.

Mayuni, E.L. 2012. Dermatosis (Kelainan Kulit) Ditinjau dari Aspek Keselamatan danKesehatan Kerja pada Pemulung di TPA Terjun Medan Marelan. Jurnal Media Kesehatan Masyarakat Indonesia, 11 (2) : 101-108.

Mustikawati, I. 2013. Perilaku Personal Hygiene Pada Pemulung Di Tpa Kedaung Wetan Tangerang. Forum Ilmiah, 10 (1) : 27-35.

Ningtiyas, F.A., Handayani, W.O., Pawenang, T.E., 2013. Sarung Tangan Latex SebagaiUpaya Pencegahan Dermatitis Kontak. Jurnal Kesehatan Masyarakat, 9 (1) : 92-99.

Sajida, A. Santi, D. Naria, E. 2012. Hubungan Personal Hygiene Dan SanitasiLingkungan Dengan Keluhan Penyakit Kulit Di Kelurahan Denai Kecamatan Medan Denai Kota Medan Tahun 2012. Jurnal Kesehatan Masyarakat Indonesia, 2(2).

Thirarattanasunthon. Siriwong. Robson. 2012. Health Risk Protection Behaviors among Scavengers in Municipality Dump Sites, Nakhon Ratchasima Province, Thailand, Asia Pacific Conference on Environmental Science and Technology Advances in Biomedical Engineering, 6:415-420.

Wirawan, A. Nurullita, U. Astuti, R. 2011. Hubungan Higiene Perorangan DenganSanitasi Lapas Terhadap Kejadian Penyakit Herpes Di Lapas Wanita Kelas II A Semarang. Jurnal Kesehatan Masyarakat Indonesia, 7 (1) : 5970.

Yansen, I. W. Arnatha, I. M. 2012. Analisis Finansial Sistem PengelolaanSampah Di Wilayah Kecmatan Mengwi Kabupaten Badung. Jurnal Ilmu Teknik Sipil, 16 (1) : 107-116. 